\title{
Major Challenges Affecting Financial Performance of Microfinance Institutions in Rwanda
}

\author{
Jean Bosco Harelimana ${ }^{1, *} \&$ Musangamfura Ignace ${ }^{1}$ \\ ${ }^{1}$ Institut d'Enseignement Superieur de Ruhengeri, Musanze, Rwanda \\ *Correspondence: Institut d'Enseignement Superieur de Ruhengeri, P.O.B. 155 Musanze, Musanze, Rwanda. E-mail: \\ harelijordan@yahoo.fr
}

Received: September 5, 2018

Accepted: September 25, $2018 \quad$ Online Published: October 17, 2018

doi:10.5430/mos.v5n4p41

URL: https://doi.org/10.5430/mos.v5n4p41

\begin{abstract}
This paper sought to determine the specific challenges affecting financial performance of Microfinance institutions (MFIs) in Rwanda.

This study used the cross-sectional survey research design. The target population of the study was 199 respondents from clients of selected Microfinance institutions and 53 respondents from managers and staff of MFIs. A questionnaire was used to collect data. The data was first explored for the underlying factor structure among the study variables through factor analysis. Thereafter, the study undertook both descriptive and inferential statistical analyses.

The findings revealed that liquidity, NPL, return on asset and return on equity are powerful instrument of financial performance of MFIs in Rwanda, it assumes that the strategies to be taken in order to address the main challenges facing MFIs in Rwanda are: Legal and Regulatory environment, Support infrastructure, Client Protection, Financial inclusion, Financial Education as well as Gender and Youth inclusion. The policy and law should also be reviewed to allow the transformed MFIs a tax holiday and exempt from tax any assets donated or transferred to the deposit taking microfinance institutions.
\end{abstract}

Keywords: microfinance challenges, financial inclusion, financial performance

\section{Introduction}

Microfinance Institution is perceived as a sustainable instrument to fight poverty in the world. It concerns the process of giving low-income people access to financial services, by lending small amounts of money to people who usually would not be able to borrow from traditional financial institutions. Microfinance is defined as the provision of financial services (savings, loans, and insurance) to relatively low income clients who typically lack access to normal commercial bank products. Microfinance loans are typically granted to groups or individuals backed by non-traditional collateral (Bamwesigye, 2008).

The concept microfinance was born in Bangladesh from the Grameen Bank, founded by Muhammad Yunus in 1976, and it has enabled the poor population of Bangladesh which is up to six millions persons, to have access microcredit (Bamwesigye, 2008).

With the Grameen Bank as model for success in the microfinance industry, other such institutions gradually emerged around the world and helped the poor to save their little as well as providing with them credit so that they would start or expand their small business enterprises. The most known microfinance institutions in developing world include: ASA founded in 1978 in Bangladesh, Bank Dagang Bali (BDB) found in 1984 in Indonesia (Saloner, 2007).

The success of these Microfinance Institutions led various development approaches, international development agencies, non-governmental organizations, and others aimed at poverty reduction in developing countries to support the creation of Microfinance Institution. Consequently there were over 3,000 Microfinance Institutions serving more than 90 million of the world's poor in 2004 as indicated by Microcredit Summit Campaign.

To improved financial services provide the poor an opportunity to improve their livelihoods and, alongside with 
social services, can contribute to poverty reduction. The financial services needed do not cover micro credit alone, but also other services are in demand. These include above all savings, but also money transfer services, micro insurance and micro leasing, all of which can play an important role in the economic empowerment of the poor.

In Africa, the concept of microfinance is not new, as savings and credit groups that have operated for centuries include the "susus" of Ghana, and "tontines" in West Africa. Additionally, from the international year of microcredit most of the African countries have developed in their Poverty Reduction Strategy Paper some actions concerning microfinance, with the aim to improving financial services offered, in particular mobilizing people to save and provide credit to poor people which enable them to contribute in stimulating economic growth. The most known Microfinance Institutions in Africa include the Amhara Credit and Savings Institution in Ethiopia, Association Al Amana for the Promotion of Micro-Enterprises Morocco in Morocco, National Microfinance Bank (NMB) in Tanzania, and the Equity Building Society in Rwanda (Tanoh, 2012).

However, Microfinance Institutions in Africa are not enough. As indicated by Calgagovski et al (1991), Africa lags behind others regions of similar size and structure. Its gross domestic savings averaged 8 percent in the 1980s, while for the same period South East Asia, and especially Newly Industrialized Economies (Republic of South Korea, Taiwan, Singapore) reached respectively 23 and 35 percent. Lack of access to finance has been identified as one of the major constraints to small business growth, the reason is that provision of financial services is an important means for mobilizing resources for more productive use, the extents to which small firms can save and accumulate own capital for further investment.

Moreover, Small enterprises and most of the poor population in sub-Saharan Africa have very limited access to deposit and credit facilities and other financial services provided by formal financial institutions. For example, in Ghana and Tanzania, only about 5-6 percent of the population has access to the banking sector. This lack of access to financial services from the formal financial system is quite striking, when one considers that in many African countries the poor represent the largest share of the population and that the microfinance sector is an important part of the economy (Anupam et al, 2004).

In Rwanda, Microfinance institutions are widely spread across Rwanda and have increased significantly in number over the last 5 years and continue to play a significant role in accelerating financial inclusion. The Rwandan microfinance system comprised of 15 microfinance institutions (under the legal status of limited company); 479 savings and credits cooperatives (SACCOs): These include 416 U-SACCOs SACCOs and 63 non U-SACCOs. All these institutions are regulated and supervised by BNR (BNR Annual financial report, 2016).

The microfinance sector and especially U-SACCOs continue to play a significant role in accelerating financial inclusion in Rwanda bringing financial services to the unbanked population.

According to Finscope Survey (2016), around 33 percent of adult Rwandans (2 million) used U-SACCO services in 2016, up from $22.3 \%$ in 2012. Umurenge SACCOs played a significant role in pushing out the boundaries of formal financial access. It takes an average of 45 minutes for adult Rwandans to reach U-SACCOs premises. The microfinance sector is greatly linked to the banking sector, the total placements of MFIs within the banking system stood at $37 \%$ of their total assets from $38 \%$ in 2015. The U-SACCOs deposits within the banking system account for 56 percent of their total assets.

The growth of assets components was uneven. Loans, which constitute $52 \%$ of total assets of MFIs, grew by $27.6 \%$. Other elements of MFIs' assets are: cash in vault and in Banks (39\%), investments in T-bills and other placement and other assets. First, credit demand declined, especially in 2016, which is also related to moderate economic growth observed in 2016. Second, the uptick in credit risk also caused some MFIs to slow down their lending pace.

The microfinance sector remains well capitalized, with aggregate capital adequacy ratio (CAR) of $30.3 \%$ in 2016 compared to the $15 \%$ prudential requirement. The increase of MFIs equity reflects the capital injection in the sector as paid up capital, which constituted of over $38 \%$, increased by $13.2 \%$ between 2015 and 2016. Further, the increase has also been fuelled by earnings retained which increased by $31.8 \%$. This level of capitalization is high enough to enable MFIs to weather moderate shocks to their balance sheets and absorb losses that may result from NPLs, (BNR, 2016).

Government of Rwanda, in its attempt to strengthen the private sector and make a dent into the poverty level in Rwanda, deemed it necessary to carry out a contextual analysis of the microfinance sector in Rwanda, in order to develop an appropriate microfinance strategy which would ensure effective provision of financial services. The National Bank of Rwanda supervises licensed institutions through the risk based supervision framework for onsite and offsite surveillance where banks report on a monthly basis. The supervisory tools used in supervising banks and 
MFIs include: offsite surveillance methodologies such as CAMELS model that stands for Capital Adequacy, Asset quality, Management quality, Earnings, Liquidity, and Sensitivity to market risk; onsite inspections: for the purpose of assessing risk management quality and compliance; and Risk Based Supervision.

Rwanda's microfinance sector has registered steady growth rates over the last years, with a positive effect on financial inclusion in the country, especially with the introduction of Umurenge SACCOs in every sector, the aggregate performance of the sector in terms of portfolio quality and profitability has been weak.

Portfolio quality remains one of the main challenges, which has been exacerbated over the years by inadequate credit risk assessment and monitoring, insufficient financial education and mistrust towards financial institutions. Although Rwanda has come a long way and now records single-digit NPLs, the level of bad loans is still well above the 5\% threshold set by BNR (BNR, 2015).

Lack of appropriate risk management systems, most MFIs are characterized by inappropriate risk management frameworks and tools and therefore their capacity to identify, monitor, measure and manage risks is weak. This weakness is often related to poor MIS and poor internal capacities on risk management. As MFIs continue to grow and expand rapidly, serving more customers and attracting more investment and funds, they need to strengthen their internal capacity to identify and anticipate potential risks to avoid unexpected losses. Most MFIs have some risk management policies in place, but usually lack a comprehensive framework that would give them a complete picture of the risks they are exposed to. Poor performing MIS often prevent the MFIs to produce timely and reliable information that should constitute the basis for a sound risk management framework.

Low transparency levels, Effective Interest Rate (EIR) or Annual Percentage Rate (APR) are important elements of a transparent loan agreement. Ideally, the loan contract should include the total cost of the loan expressed as APR and MFIs should duly inform clients of lending terms and conditions. Even more relevant to the point of transparency, terms and conditions of products and services offered should not only be indicated in official documents, but also communicated to clients by using expressions they can easily understand. This means that Loan Officers have the duty to ensure their clients have a good understanding of what the loan entails, making sure they are effectively overcoming linguistic and educational barriers.

Poor product design, in general, microfinance products should be convenient (e.g. in terms of geographical proximity, user-friendly opening hours), accessible. The need to develop increasingly flexible and responsive financial products is one of the most compelling challenges for institutions operating in the microfinance space: limited companies, SACCOs and banks alike. There is a need to adapt the right products and services to fit different segments of the population, especially in a country with a high youth population. Interviewees acknowledge the importance of tailoring terms and conditions of existing products to the needs of clients (BNR, 2015).

However, installment dates and grace periods might follow a similar pattern for all farmers, irrespective of their crop cycle, either because the credit manual doesn't differentiate among crop types and doesn't specify different requirements, or because LOs aren't sufficiently prepared and trained to assess agribusinesses. This lack of innovation can stifle the market in the medium-term, as institutions do not have a significant competitive advantage over the others because of distinctive or innovative products, Limited customer centricity, one of the key features of a successful microfinance institution is the ability to provide solutions based on a deep understanding of customer needs, preferences, and behaviors, Customer-centricity is usually mentioned as key, yet reality often shows a different picture. To effectively put the needs and aspirations of customers at the centre of business strategies and decision-making, financial service providers may have to rethink their operations and invest significant effort and resources to change not only business operations but also organizational mindsets.

Bad credit culture, this bad credit repayment history stems from the international aid and donations influx after the 1994 Genocide against Tutsi, and mixing of loans and grants which distorted the market MFIs are still struggling to inculcate a repayment culture with their clients. This and limited employment of industry best practices, contribute to the relative low portfolio quality encountered in Rwanda, Skill level, MFIs find it challenging to recruit capable staff due to a low general skill level, which is not uncommon for post-conflict environments.

Lack of donor coordination, donors is not working in a coordinated manner resulting in the duplication of efforts in a number of domains. There is also a lack of industry learning from past ineffective programming (association support, bank linkages, etc). The wheel is reinvented a lot and projects are working in silos from each other and are not geared towards the building of an inclusive financial sector and measuring of progress to this end, Underdeveloped sector infrastructure, Sector support mechanisms such as technical assistance providers, credit bureaus, audit firms, research institutions, rating agencies, and linkages with business development services (BDS) providers are either non-existent 
or not working well, which hinders the sectors advancement. In particular, the options to choose from as technical service provider in Rwanda are rather limited; institutions such as SBFIC, AFR, AMIR have to provide training or technical assistance but they are still limited.

Limited outreach in rural areas, the lack of basic infrastructure in rural and remote areas (electricity, roads, etc.) is an impediment to MFIs expansion in those zones. Notably, MFIs are not connected to any kind of payment system which limits their capacity to expand their outreach. While the closure of weak MFIs is a direct and positive effect of the new regulatory framework, it also reduced the outreach in remote rural areas, Lack of shareholders Ownership, most of Micro finances is Limited Companies which require their management to give dividends to shareholders. As they are not yet able to earn more income, shareholders are not supportive to theirs institutions because they feel like their investments are not profitable, apart of that, if Microfinance considers earning more income that serving lower income society, they will drift the mission, which is very risk to the institutions and government in general.

\section{Objectives}

The general objective of the study is to find out the challenges faced financial performance of microfinance in Rwanda and the Specific objectives are the following:

1. To analyze the main challenges affecting the MFIs' performance in Rwanda

2. To examine the status of financial performance of MFIs in Rwanda

3. To find out the relationship between MFIs challenges and financial performance of MFIs in Rwanda.

\section{Literature Review}

Most microfinance institutions are started with the target group being the middle and low income level persons, their success therefore depends on the support received form those who operate and benefit from it. Sustainability is achieved when microfinance is able to cater for its routine expenses and meet any debts that arise in the course of its operations. The literature above has considered the model of a micro finance to be very important in ensuring success.

Pyle (1997), in his study on bank risk management held that banks and similar financial institutions need to meet forthcoming regulatory requirements for risk measurement and capital. However, it is a serious error to think that meeting regulatory requirements is the sole or even the most important reason for establishing a sound, scientific risk management system. It was held, managers need reliable risk measures to direct capital to activities with the best risk/reward ratios. They need estimate of the size of potential losses to stay within limits imposed by readily available liquidity, by creditors, customers and regulators. They need mechanisms to monitor positions and create incentives for prudent risk taking by divisions and individuals.

Nagarajan (2001) in his study of risk management for microfinance institutions in Mozambique found that risk management is a dynamic process that could ideally be developed during normal times and tested at the wake of risk. It requires careful planning and commitment on part of all stakeholders. It is encouraging to note that it is possible to minimize risks related losses through diligent management of portfolio and cash-flow, by building robust institutional infrastructure with skilled human resources and inculcating client discipline, through effective coordination of stakeholders.

Crucial importance that financial institutions practice prudent credit risk management and safeguarding the assets of the institutions and protect the investors "interests. This is also true for micro finance institutions. Method used by the researchers is mixed research method. Matu (2008) carried out a study on sustainability and profitability of microfinance institutions and noted that efficiency and effectiveness were the main challenges facing Kenya on service delivery.

Soke Fun Ho and Yusoff (2009), in their study on credit risk management strategies of selected financial institutions in Malaysia the majority of financial institutions and banks losses stem from outright default due to inability of customers to meet obligations in relation to lending, trading, settlement and other financial transactions. Credit risk emanates from a banks dealing with individuals, corporate, financial institutions or sovereign entities. A bad portfolio may attract liquidity as well as credit risk. The aim of credit risk management is to maximize a bank's risk-adjusted rate of return by maintaining credit risk exposure within acceptable boundary.

The efficient management of credit risk is a vital part of the overall risk management system and is crucial to each bank's bottom and eventually the survival of all banking establishments. It is therefore important that credit decisions 
are made by sound analyses of risks involved to avoid harms to bank's profitability. They held effective management of credit risk is an essential component of a comprehensive technique to risk management and critical to the long-term success of all banking institutions.

Orua (2009) did a study on the relationship between capital structure and financial performance of microfinance institutions in Kenya it revealed that short-term debt significantly impacted MFI outreach positively. Long term debt however showed positive relationship with outreach but was not significant with regard to default rates, both short and long term debts showed expected results but were not significant indicating that maturity may not necessarily be of essence. Generally highly leveraged MFIs were found to perform better by reaching out to more clients. It was also revealed that such MFIs also enjoyed economies of scales and therefore were better able to deal with moral hazards and adverse selections which also enhanced their ability to manage risks.

Sindani (2012) in her study on Effectiveness of Credit Management System on Loan Performance: Empirical Evidence from Micro Finance Sector in Kenya found out that Credit terms formulated by the microfinance institutions do affect loan performance; the involvement of credit officers and customers in formulating credit terms affects loan performance. Interest rates charged had a negative effect on the performance of the loans, the higher the interest rates the lower the loan performance.

Credit risk controls adopted by microfinance institutions have an effect on loan performance, credit insurance, signing of covenants with customers, diversification of loans, credit rating of customers, reports on financial conditions, refrain from further borrowing had an effect on loan performance. Collection policies adopted by microfinance institution had an effect on loan performance, stringent policy had a great impact on loan performance, and the lenient policy had an effect but was not as great as that of stringent policy.

Achou and Tenguh (2008) also conducted research on bank performance and credit risk management found that there is a significant relationship between financial institutions performance (in terms of profitability) and credit risk management (interms of loan performance). Better credit risk management results in better performance. Thus, it is of Different models attract people with different needs and therefore a specific model should be used when it best fits the desired target group.Various researchers have addressed different aspects of microfinance institutions. Wanjiru (2000) studied the factors that influence productivity of credit officers in microfinance institutions. The study established that productivity of the officers depends on the remuneration and other benefits obtained from their job responsibilities. In some institutions the officers were remunerated based on the successful loan management. James (2007), studied the credit rationing by micro finance and its influence on the operations of the small and micro enterprises. The study established that, credit rationing is a tool used by most micro finance institutions to hedge the effects of default by the borrowers. As a measure, the study established that the institutions require some form of collateral before giving loans. The effects of this rationing based on collateral, the study established, has denied many small and micro enterprises access to the financial services required for growth.

Lack of skilled personnel is the common problem in Ethiopian Microfinance Institutions. This situation is more exacerbated by high turnover of experienced personnel either for the need for better jobs or hate to work in rural areas with minimal facilities provided as compared to urban areas which offer better living conditions. There is also a problem of using modern core finance technologies for many of MFIs specially those microfinance institutions operating in remote rural areas having poor infrastructure development. As a result, there are problems of non-standardized reporting and performance monitoring system. On the other hand, MFIs face challenges of obtaining loans in the existing financial market, particularly from banks, which hampers strive for addressing various needs of clients. There is an illegal way of doing the micro financing business from the side of the government, NGOs and other agencies which continue to provide uncollectible loans by violating the proclamations ratified by the House of People's Representatives. Apart from this, there are deep concerns within the microfinance sector about the growing issue of inflation on the profitability of MFIs, and the ability to maintain low interest rates (Ebisa et al., 2013).

\section{Research Design}

Research design is a specification of methods and procedures for acquiring the information needed according to (Church hill Gilbert A, 1977).

The design of this study was in such a way secondary and primary data were first to be collected then analyzed to relate to findings and then see if they meet the objectives. A descriptive survey design was used in this study where data describing the prevailing situation was obtained from across section of the population. A descriptive analytical 
approach was utilized to interpret data into meaningful information to answer research questions.

\subsection{The Population of the Study}

Target population in statistics is the specific population about which information is desired. According to Ngechu (2004), a population is a well-defined or set of people, services, elements, and events, group of things or households that are being investigated.

The target population for this study was including the staffs who work in selected MFIs such as, GOSHEN, DUTERIMBERE, VISION, RIM AND INKINGI. Target population of this study was 65 employees of mentioned MFIs.

\subsection{Sampling Technique}

According to Kakooza (1990), a sample is a set of population under study, while sampling technique refers to methods/techniques used in evaluating the specified population sample.

The formula is as follows: $\mathrm{n}=\frac{N}{1+N(e) 2}$

N: Target Population

n: Number of samples

e: Error tolerance $=0.1$

$\underset{\mathrm{n}=}{\mathrm{N}=65_{N}} \frac{65}{1+N(e) 2}=\frac{65}{1+65(0.1) 2}=\frac{65}{1+65(0.01)}=\frac{65}{1.65}=43$

\subsection{Primary Data}

Primary data is the data collected specifically for the purpose of investigation at hand. Primary data of this research was collected directly from the staff of selected MFIS. The researcher obtained this data through primary sources like: Questionnaires, Interviews, and Observation methods of data collection.

\subsection{Secondary Data}

In collecting secondary data, the researcher used documentary review methods. Documents were used as sources of necessary secondary information such as magazines, selected MFIS staffs feedback form, reports and journals, and web sites with information related to selected MFIS to the relevant research.

\subsection{Validity and Reliability Tests}

The researcher used the test-retest reliability technique where a pilot test of four questionnaires were given to financial executive staff from finance, accounts commercial department in selected MFIS so as to examine the appropriateness of responses given by respondents before applying the questionnaire to the entire population.

The researcher used pre-test technique to confirm the validity of the instrument by developing a pilot set of questions and asking them to a number of people, two from human resource department, three from the Government portfolio unit, five from public accounts and reporting unit and five from the office of Human Resource Manager who know little about the subject matter to verify whether the questions are clearly worded and easily understood and whether the respondents know the answers or not.

\subsection{Method of Data Analysis}

The researcher used this method while analyzing data and information that has been collected during the research in order to draw figures and tables that illustrate realities to discuss in the study using SPSS program. Thus, the statistic method helps the researcher to quantify data and to make it accessible to rigorous mathematics treatments, (Aktouf, 1996).

This method helped the researcher especially in presentation and analysis of quantified data like in tables with reference to frequencies of appearance of answers and on percentages. 


\section{Results and Discussions}

This section discusses the interpretation and presentation of the findings obtained from the field on the major challenges affecting financial performance of Microfinance Institutions in Rwanda. Descriptive and inferential statistics were used to discuss the findings of the study. The study targeted a population size of 43 respondents. This response rate was satisfactory to make conclusions for the study.

Table 1. Gender of Respondents

\begin{tabular}{llcccc}
\hline & & Frequency & Percent & Valid Percent & Cumulative Percent \\
\hline \multirow{3}{*}{ Valid } & Male & 27 & 50.9 & 62.8 & 62.8 \\
& Female & 16 & 30.2 & 37.2 & 100.0 \\
& Total & 43 & 81.1 & 100.0 & \\
Missing & System & 10 & 18.9 & & \\
Total & & 53 & 100.0 & & \\
\hline
\end{tabular}

Source: Primary data, 2018

The above table shows the gender of staff, $62.8 \%$ of staff was male followed by $37.2 \%$ of female. This means that in the selected MFIs, the great number of staff was male.

Table 2. Existence of Selected MFIs

\begin{tabular}{llcccc}
\hline & & Frequency & Percent & Valid Percent & Cumulative Percent \\
\hline \multirow{4}{*}{ Valid } & Less than 5years & 9 & 17.0 & 20.9 & 20.9 \\
& Between 5 to 10 years & 9 & 17.0 & 20.9 & 41.9 \\
& Between 10 to 15 years & 21 & 39.6 & 48.8 & 90.7 \\
& Above 15 years & 4 & 7.5 & 9.3 & 100.0 \\
& Total & 43 & 81.1 & 100.0 & \\
Missing & System & 10 & 18.9 & & \\
Total & & 53 & 100.0 & & \\
\hline
\end{tabular}

Source: Primary data, 2018

The findings in the above table also show the duration the microfinance institutions had been operating. From the study, the majority of these firms as shown by $48.8 \%$ of the respondents had been operating for $10-15$ years, $20.9 \%$ of the firms had been operating in 5-10 years, $20.9 \%$ of the firms had been in operation for less than 5 years.

Table 3. Number of Clients in Selected MFIs

\begin{tabular}{llcccc}
\hline & Frequency & Percent & Valid Percent & Cumulative Percent \\
\hline \multirow{4}{*}{ Valid } & Less than 5000 clients & 8 & 15.1 & 18.6 & 18.6 \\
& Between 10000 to 20000 clients & 21 & 39.6 & 48.8 & 67.4 \\
& Between 25000 to 50000 clients & 9 & 17.0 & 20.9 & 88.4 \\
& Above 50000 clients & 5 & 9.4 & 11.6 & 100.0 \\
& Total & 43 & 81.1 & 100.0 & \\
Missing & System & 10 & 18.9 & & \\
Total & & 53 & 100.0 & & \\
\hline
\end{tabular}

Source: Primary data, 2018

The findings in the above table also show the number of clients of selected MFIs. From the study, the majority of these firms as shown by $48.8 \%$ of respondents said that they have number of customer between 10,000 to 20,000, followed by $20.9 \%$ which were between 25000 to 50000 clients, $18.6 \%$ were less than 5000 clients, while $11.6 \%$ said that the number of customer was above 50,000 clients. 
Table 4. The MFI Use Client Appraisal in Credit Management

\begin{tabular}{llcccc}
\hline & & Frequency & Percent & Valid Percent & Cumulative Percent \\
\hline & Very great extent & 9 & 17.0 & 20.9 & 20.9 \\
& Great extent & 25 & 47.2 & 58.1 & 79.1 \\
Valid & Moderate extent & 8 & 15.1 & 18.6 & 97.7 \\
& Low extent & 1 & 1.9 & 2.3 & 100.0 \\
& Total & 43 & 81.1 & 100.0 & \\
Missing & System & 10 & 18.9 & & \\
Total & & 53 & 100.0 & & \\
\hline
\end{tabular}

Source: Primary data, 2018

The study sought to determine the extent to which MFIs used client appraisal in Credit Management, from the findings $58.1 \%$ of the respondents indicated to a great extent, $20.9 \%$ of the respondents indicated to a very great extent whereas $18.6 \%$ of the respondents indicated to a moderate extent, this implies that most MFIs used client appraisal in Credit Management to a great extent.

Table 5. The MFI Use Credit Risk Control in Credit Management

\begin{tabular}{llcccc}
\hline & & Frequency & Percent & Valid Percent & Cumulative Percent \\
\hline & Very great extent & 9 & 17.0 & 20.9 & 20.9 \\
& Great extent & 25 & 47.2 & 58.1 & 79.1 \\
Valid & Moderate extent & 8 & 15.1 & 18.6 & 97.7 \\
& Low extent & 1 & 1.9 & 2.3 & 100.0 \\
& Total & 43 & 81.1 & 100.0 & \\
Missing & System & 10 & 18.9 & & \\
Total & & 53 & 100.0 & & \\
\hline
\end{tabular}

Source: Primary data, 2018

The study sought to determine the extent to which MFIs used credit risk control in Credit Management, from the findings $58.1 \%$ of the respondents indicated to a great extent, $20.9 \%$ of the respondents indicated to a very great extent whereas $18.6 \%$ of the respondents indicated to a moderate extent, this implies that MFIs used credit risk control in Credit Management to a great extent.

Table 6. The MFI Use Loan Recovery Process in Credit Management

\begin{tabular}{|c|c|c|c|c|c|}
\hline & & Frequency & Percent & Valid Percent & Cumulative Percent \\
\hline \multirow{4}{*}{ Valid } & Very great extent & 9 & 17.0 & 20.9 & 20.9 \\
\hline & Great extent & 25 & 47.2 & 58.1 & 79.1 \\
\hline & Moderate extent & 9 & 17.0 & 20.9 & 100.0 \\
\hline & Total & 43 & 81.1 & 100.0 & \\
\hline Missing & System & 10 & 18.9 & & \\
\hline Total & & 53 & 100.0 & & \\
\hline
\end{tabular}

Source: Primary data, 2018

The study sought to determine the extent to which MFIs use collection policy in Credit Management, from the findings $58.1 \%$ of the respondents indicated to a great extent, $20.9 \%$ of the respondents indicated to a very great extent whereas $20.9 \%$ of the respondents indicated to a moderate extent. This implies that MFIs use collection policy in Credit Management to a great extent. 
Table 7. The MFIs Use Transformation Related Issues

\begin{tabular}{llrrrr}
\hline & & Frequency & Percent & Valid Percent & Cumulative Percent \\
\hline \multirow{3}{*}{ Valid } & Very great extent & 7 & 16.2 & 16.2 & 16.2 \\
& Great extent & 29 & 67.4 & 83.6 & 83.6 \\
& Moderate extent & 7 & 16.2 & 16.2 & 100.0 \\
Missing & Total & System & 43 & 81.1 & 100.0 \\
Total & & 10 & 18.9 & & \\
\hline
\end{tabular}

Source: Primary data, 2018

The study sought to determine the extent to which MFIs use transformation related issues, from the findings $67.4 \%$ of the respondents indicated to a great extent, $16.2 \%$ of the respondents indicated to a very great extent whereas $16.2 \%$ of the respondents indicated to a moderate extent, this implies that MFIs use transformation related issues to a great extent.

\subsection{Status of MFIs in Rwanda in Term of Financial Performance}

It would probably take longer, because several microfinance institutions issue loans with terms larger than 12 months. The good news is that this situation is changing (and will hopefully continue to change) positively, thanks to increasing competition that is bringing down the average loan size across the microfinance sector, thus helping microfinance institutions reach more people. However, policy makers need to address the tendency for MFIs to increasingly target higher end clients, thus shifting from their initial mission to lift poorer strata of the population out of poverty.

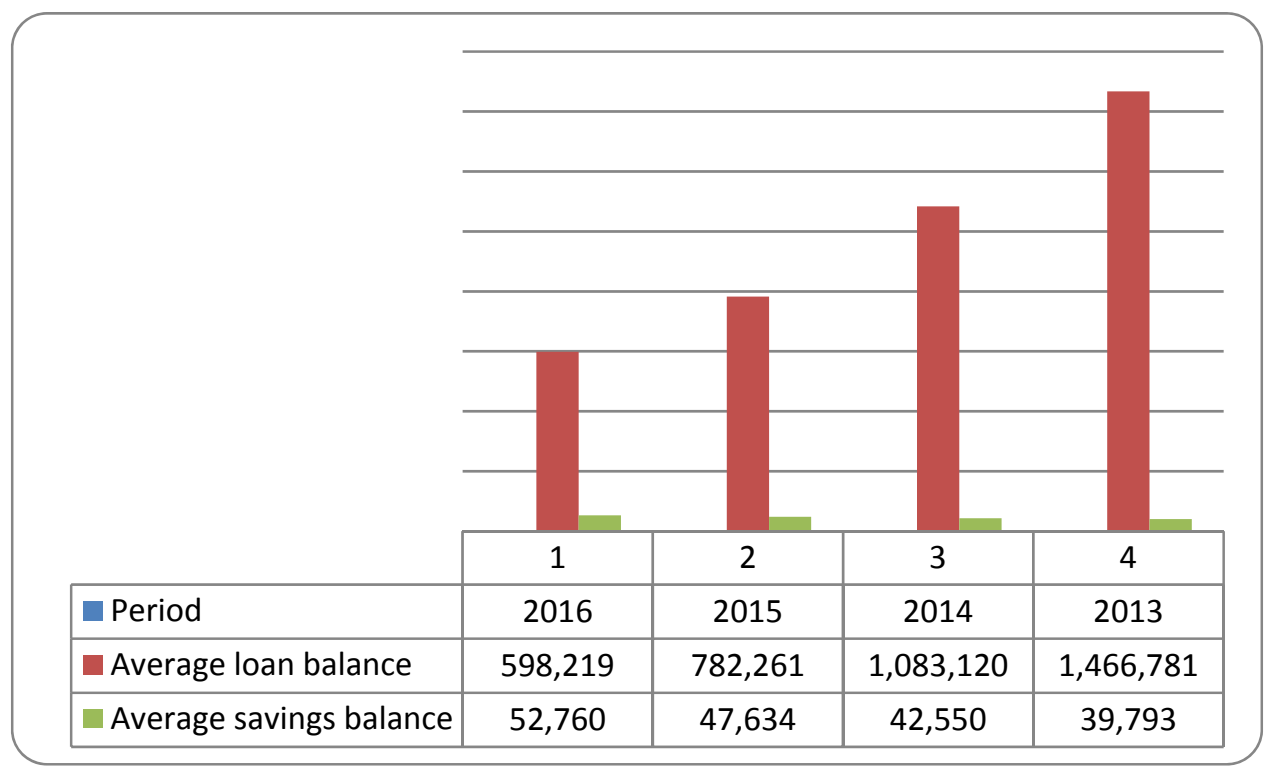

Figure 1. Comparison between Median Saving Balances and Median Loan Balances (000 Rwf)

Source: Research findings, 2018

Data from AMIR revealed that there is an overall tendency across the microfinance sector to reduce loan sizes as shown in figure 4.1, the average loan size was FRW 1,466,781 in 2013, and shrank down to an average of only FRW 782,261 (-47\%). Average savings balance grew in opposite direction, from an average of FRW 39,793 in 2013 , up to FRW 52,760 in $2016(+20 \%)$. It shows that microfinance institutions are increasingly interested in poorer market segments for lending activities, and that the population is increasingly gaining confidence in the microfinance institutions and entrusting them with their savings.

\subsubsection{Portfolio Quality}

It is of paramount importance for a microfinance institution to monitor, and maintain the quality of its loan portfolio. Indeed, the loan portfolio is a microfinance institution's largest asset, and as such, it constitutes also the largest 
source of risk. The most common measure of loan portfolio quality in microfinance is the Portfolio at Risk (PAR)

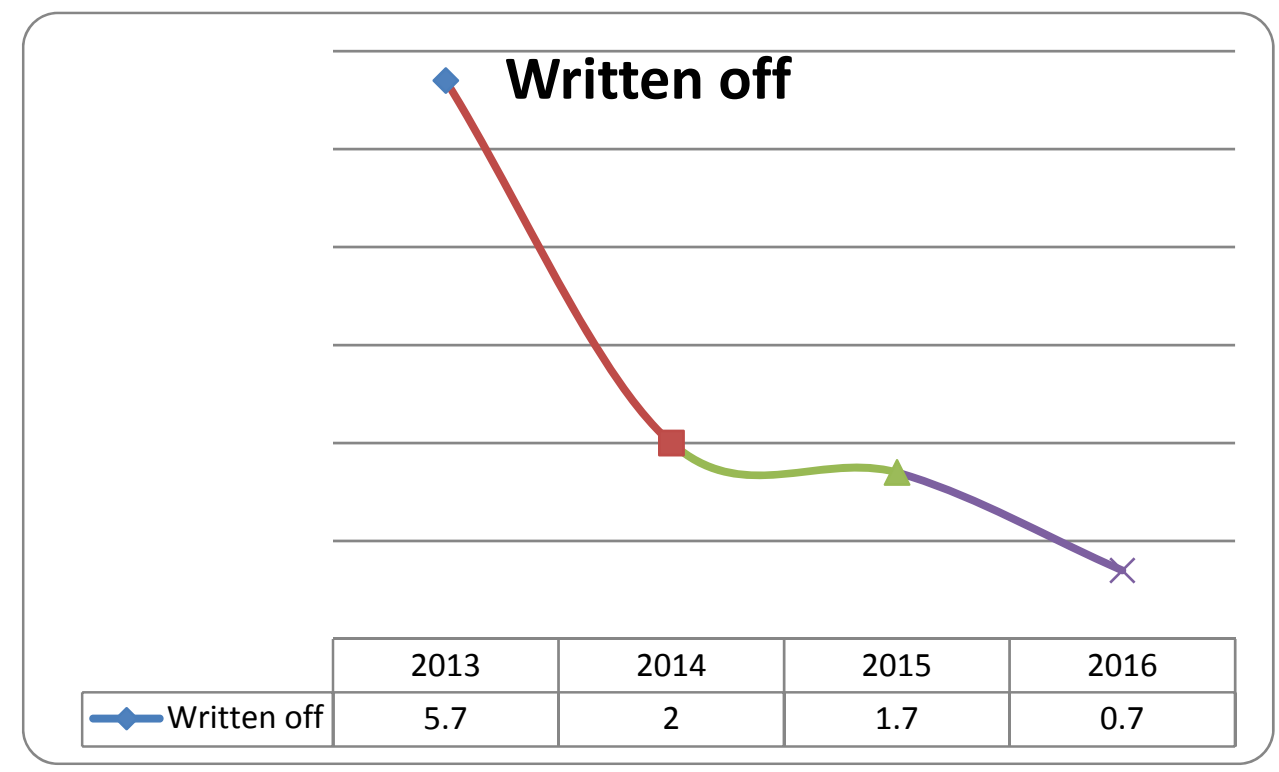

Figure 2. Trend in NPL (average, 2013- 2016)

Source: Research findings, 2018

The above figure have showed the trend in NPL where it was referred to the Portfolio quality has fluctuated between $6.8 \%$ and $8.9 \%$ over the period 2013 to 2016; well above the accepted standard of 5\%. This rate is influenced by the performance of MFIs, which have seen their portfolio steadily worsening from only $8.90 \% 2013$, to $7.5 \%$ in 2016 .

\subsubsection{Write-off Ratio}

In this section the researcher wanted to show the write-off ration of MFIs during the covered period of study

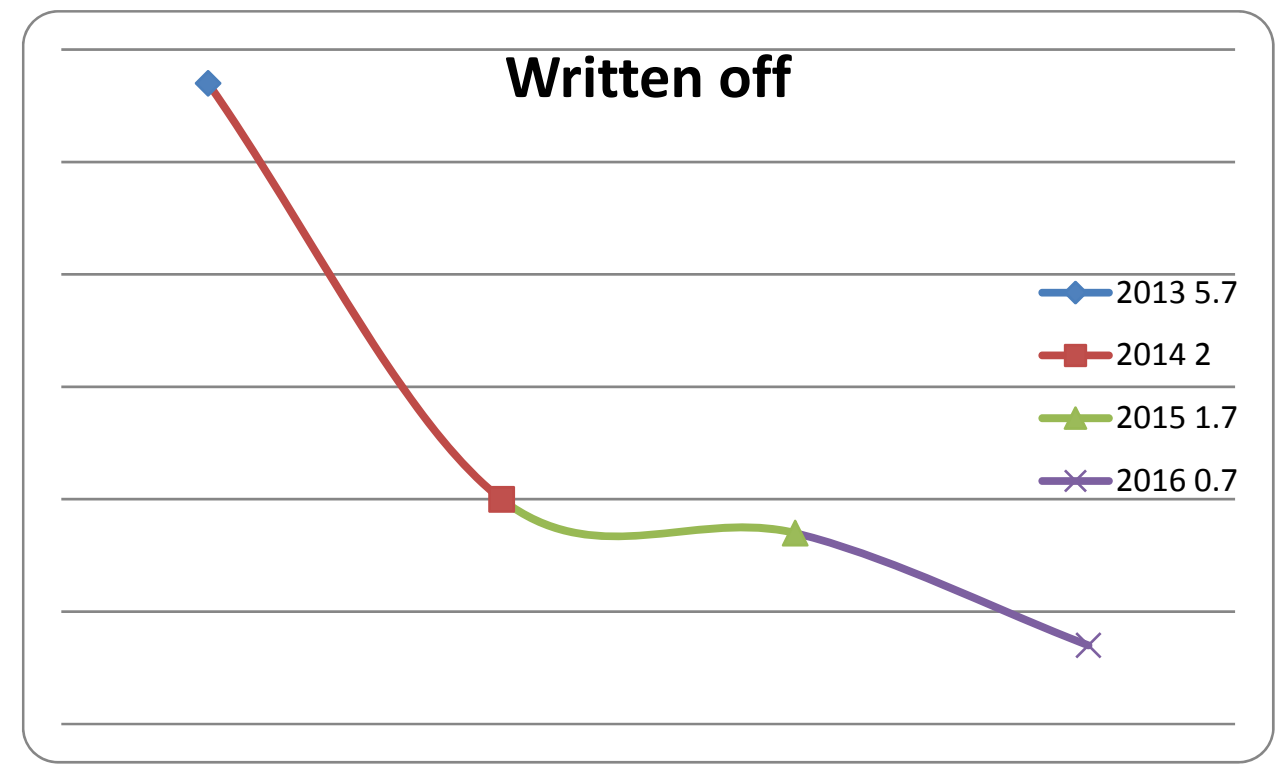

Figure 3. Evolution of Write-Off Ratio per Type of Institution

Source: Research findings, 2018 
The above figure shows that Higher Write-Off Ratios observed among MFIs where from 2013 was 5.7\%, 2\% in $2014,1.7 \%$ in 2015 and $0.7 \%$ in 2016. This implies that the quality of MFIs loan portfolio was not better than the whole microfinance sector almost similarly at high risk, irrespective of institutional category.

\subsubsection{Efficiency and Profitability of MFIs}

This section analyses four indicators in this performance category: Operating Expense Ratio (OER), Cost per Borrower Ratio, Personnel Productivity and Loan Officer Productivity. These indicators give a picture on the status of institutional performance in the area of operations. Productivity indicators compare inputs (staff, loan officers, budget, etc.) to outputs (outreach: number of people reached with savings or loan products, loan portfolio). Efficiency indicators take into consideration the costs of inputs under consideration, and compare them to outputs.

\subsubsection{Return on Equity and Return on Assets Ratios}

The most commonly used indicator to measure microfinance institution profitability is the Return on Equity. It measures the return on owners' investment in the MFI. It is also used to measure commercial viability.

On the other hand, the Return on Assets is used to measure overall profitability. It is an equivalent of profit margin, as it shows how an institution put all its assets at use to generate revenue.

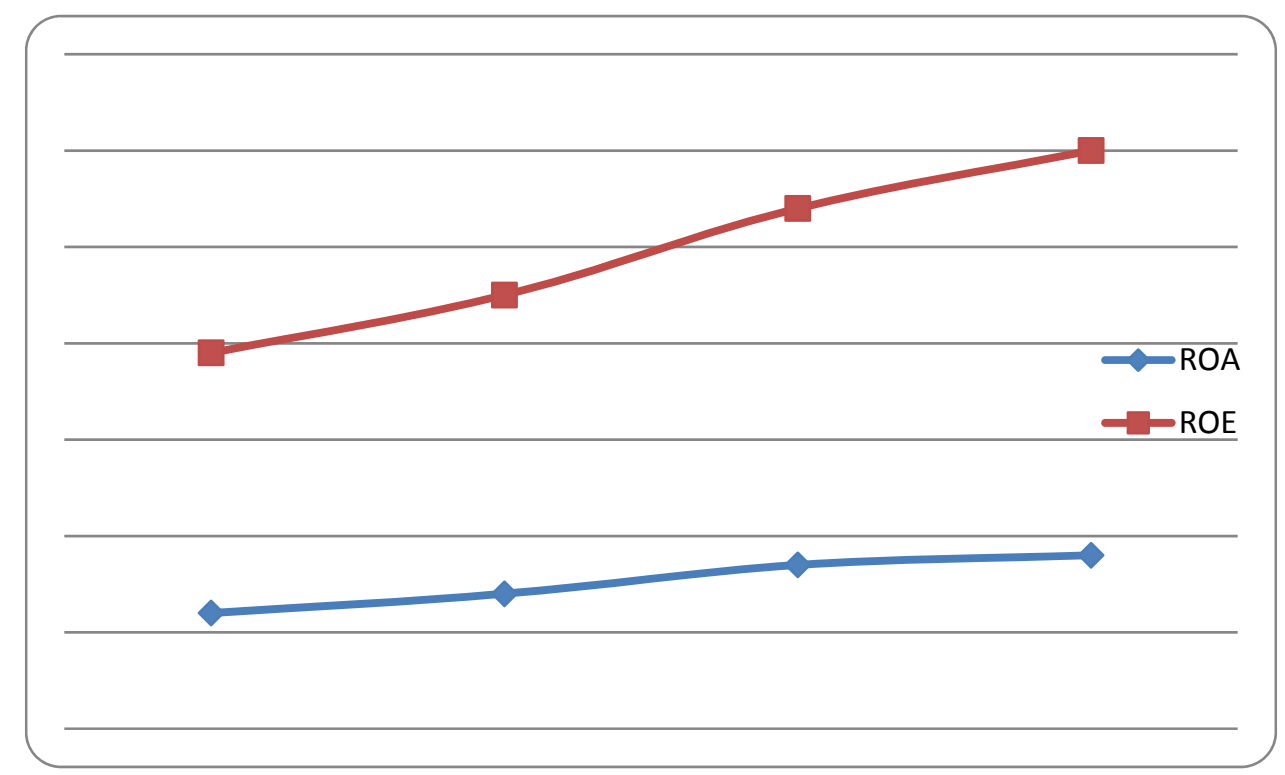

Figure 4. Evolution of ROA and ROE of MFIs (2013-2016)

Source: Research findings, 2018

Both the ROE and ROA have increased consistently over the period June 2013-June 2016. The ROE increased from $3.9 \%$ to $6 \%$; and the ROA from $1.2 \%$ to $1.8 \%$ (54\% and 50\% growth respectively). This implies that, the analysis of AMIR data revealed that there have been different stories per category of MFIs.

However, the same problems encountered in 2013-2014 might arise again in the short term, if there are no clear strategies in place to maintain a healthy loan portfolio. In addition, the efficiency of limited companies is below par during the period 2013-2016: the cost per borrower was the highest in the Rwandan microfinance industry for this category of institutions during the period 2013-2016. This was due to relatively high levels of operating expenses (as evidenced by operating expense ratio) in comparison to other types of microfinance institutions. However, the overall trend was positive, for both the ROE and ROA, thanks to the following factors: Increasing liabilities: the level of leverage - the proportion of equity to debt - is an important factor that affects the profitability of microfinance institutions.

Indeed, the ROE increases proportionally to the increase in debt, all other things being constant4. As a result, MFIs usually finance most of their assets through debt, to achieve higher ROE. Debt to equity has increased positively over the period under review, for the whole microfinance sector in general, in spite of the slight decrease registered in the period 2014. 
There has been consistent improvement in productivity (e.g. overall loan officer productivity ratio increased) over the period under review that possibly impacted positively on the profitability of the sector in general.

There have been consistent gains in efficiency over the period under review (for example, the cost per borrower improved in general, except for limited companies).

\subsubsection{Portfolio Yield}

This indicator measures the amount a microfinance institution receives from its clients (interests, commission, fees, etc.) during a specific period. It takes into account all fees, discounts and special charges. The portfolio yield helps an MFI to assess how efficient its loan collections are, when compared to average effective lending rate. In addition, the portfolio yield is used to determine the profit margin from operations of an MFI [Profit margin=Portfolio Yield (Operating Expense Ratio + Impairment Expense Ratio + Financial expense Ratio)]

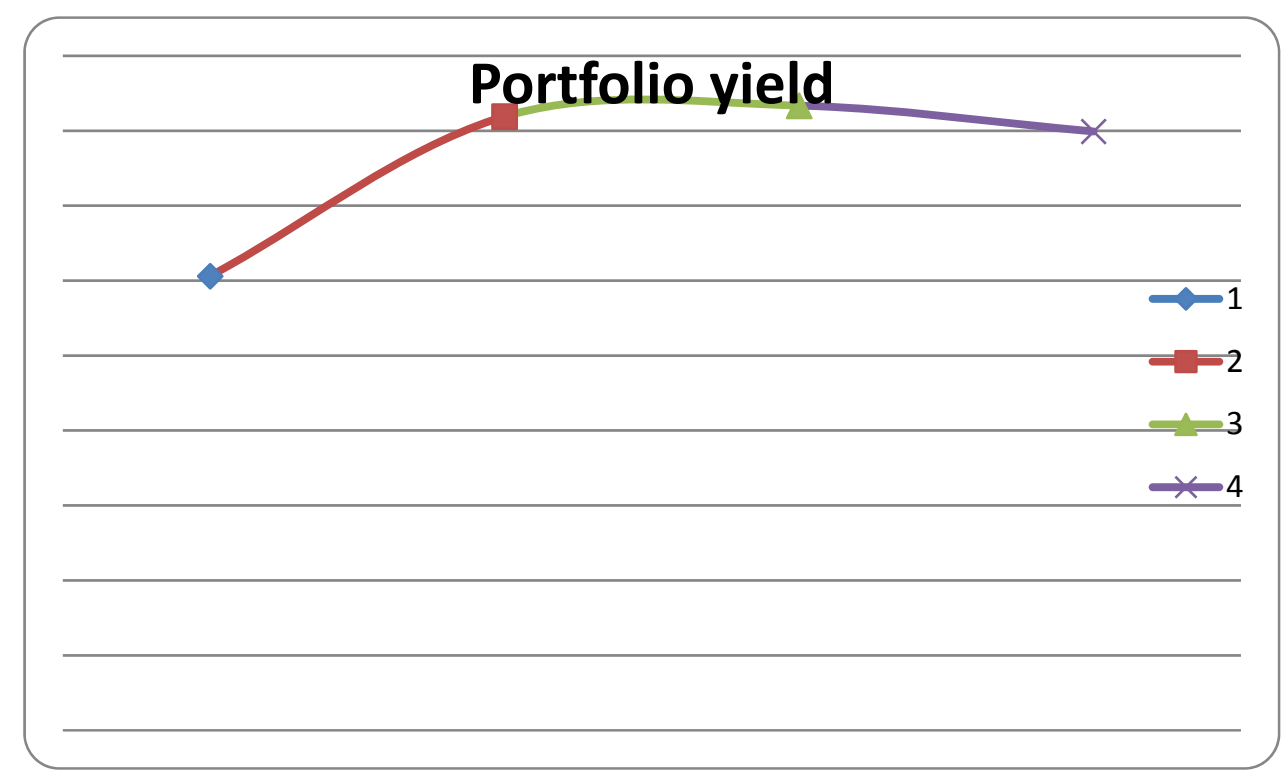

Figure 5. Evolution of Portfolio Yield 2013-2016.

Source: Research findings, 2018

It is also a good indicator to assess a microfinance institution' ability to generate enough revenue to cover its expenses (financial and operating expenses). This ratio has declined over the period under review, for all types of microfinance institutions: it decreased from an average of $17.2 \%$ in 2013 ; to $16 \%$ in 2016 (fig. 37). One possible cause of such trend is an increase in competition that pushes prices downwards. In addition, AMIR and other stakeholders have disseminated the SMART Campaign' Client Protection Principles and AMIR Code of Conduct since 2013, and this has possibly influenced microfinance institution's pricing strategies, and adopted more responsible prices. Declining interest rates were widely adopted and gradually phased out flat interest rates.

The correlation analysis was carried out between the variables of the study using Pearson correlation coefficient. This was due to the test whether there existed interdependency between independent variables and also to examine if there exist significant relationship between the independent variables (major challenges and financial performance) and the dependent variable that is financial performance of MFIs. 
Table 8. Correlation Matrix of Independent Variables

\begin{tabular}{|c|c|c|c|c|}
\hline & & $\begin{array}{l}\text { To what extent do the } \\
\text { MFIs use credit risk } \\
\text { control in Credit } \\
\text { Management? }\end{array}$ & $\begin{array}{c}\text { The use of credit } \\
\text { checks on regular } \\
\text { basis enhances credit } \\
\text { management. }\end{array}$ & $\begin{array}{l}\text { Efficiency and } \\
\text { profitability of } \\
\text { MFIs }\end{array}$ \\
\hline \multirow{6}{*}{$\begin{array}{l}\text { To what extent do the MFIs use } \\
\text { credit risk control in Credit } \\
\text { Management? } \\
\text { The use of credit checks on } \\
\text { regular basis enhances credit } \\
\text { management. }\end{array}$} & Pearson Correlation & 1 & $1.000^{* *}$ & $1.000^{* *}$ \\
\hline & Sig. (2-tailed) & & .000 & .000 \\
\hline & $\mathrm{N}$ & 43 & 43 & 43 \\
\hline & Pearson Correlation & $1.000^{* *}$ & 1 & $1.000^{* *}$ \\
\hline & Sig. (2-tailed) & .000 & & .000 \\
\hline & $\mathrm{N}$ & 43 & 43 & 43 \\
\hline \multirow{3}{*}{$\begin{array}{l}\text { Efficiency and profitability of } \\
\text { MFIs }\end{array}$} & Pearson Correlation & $1.000^{* *}$ & $1.000^{* *}$ & 1 \\
\hline & Sig. (2-tailed) & .000 & .000 & \\
\hline & $\mathrm{N}$ & 43 & 43 & 43 \\
\hline
\end{tabular}

When the variables were correlated among themselves, all were found to be associated as shown in the table 4.8. the extent do the MFIs use credit risk control in Credit Management was positively and statistically significant correlated to the efficiency and profitability of MFIs $(r=1, p>0.00)$; The use of credit checks on regular basis enhances credit management $(r=0.01, p>1$ Efficiency and profitability of MFIs was positively and significantly correlated to The use of credit checks on regular basis enhances credit management $(r=1, p>0.01)$. Finally, the use of credit checks on regular basis enhances credit management was positively and significantly correlated to the efficiency and profitability of MFIs) $(r=1.000, p>0.01)$.

\section{Conclusion}

The study found that client appraisal; credit risk control and collection policy had effect on financial performance of MFIs. Finally, the use of credit checks on regular basis enhances credit management was positively and significantly correlated to the efficiency and profitability of MFIs).

The study recommends that MFIs should enhance their collection policy by adapting a more tough policy to a lenient policy for effective debt recovery. The study also recommends that there is need for MFIs to enhance their client appraisal techniques so as to improve their financial performance. Through client appraisal techniques, the MFIs will be able to know credit worth clients and thus reduce their non-performing loans. However, there are opportunities that could tapped into in order to address challenges that are still confronting the sector: for example, a better coordination of actors, which has translated into establishment of coordination platforms at district level will hopefully contribute to improved synergy among actors. In addition, several stakeholders continued to show their commitment to improving the performance of microfinance industry over time, materialized by a number of projects involving key stakeholders such as MasterCard Foundation, ICCO Cooperation, SBFIC, Global Communities, Access to Finance and others, and innovative products.

To supervisory bodies (BNR, RCA) there is a need to intensify supervision by the central bank, in order to curb down increasing poor loan portfolio quality. Supervision mission should be coupled with advice on financial management, particularly to those institutions whose financial structure already poses some concern. It should also be risk-based, because some large institutions are worse-off in some performance areas than smaller and younger microfinance institutions, while they pose bigger threat to the overall sector performance. To capacity builders Stakeholders should work together to provide capacity building services targeting microfinance staff in key capacity areas. Microfinance institutions need particularly some support and capacity building in products design and delivery (how to develop products that target lower end market), incentive schemes to improve quality and quantity of loan and savings accounts, financial management and resources mobilization, as well performance monitoring. To all stakeholders' financial education should mostly target youth (17-20 years), and be customized and tailored to their needs, in order to increase their access to financial services. Similarly, affirmative action measures should be taken by microfinance institutions to increase the number of women that access loan, as it appears that gender equity in this areas is still far from being achieved. 


\section{References}

Abedi, S. (2000). Highway to Success, Credit Management Journal, http://leatherspinters.com

Arnold, G. (2003). Corporate Financial Management. New Jersey: Prentice Hall. Balduino, W.F.(2000a). Risk Is In. Retrieved 22/10/07 from http://www.dnb.com

Binks, M., \& Ennew, T. (1996). Financing small firms, small business and entrepreneur ( $\left.2^{\text {nd }} \mathrm{ed}.\right)$.

Binks, M., \& Ennew, T. (1997) Small business and relationship banking: the impact of participative behavior, entrepreneurship. Theory and practice, 21(4), 83-92. https://doi.org/10.1177/104225879702100406

Binks, M.R., \& Ennew, C.T. (1992). Information asymmetries and the provision of finance to small firms. International Small Business Journal, 11(1), 35-46. https://doi.org/10.1177/026624269201100103

Brigham, E.F., Gapenski, L.C., \& Daves, P.R. (1999). Intermediate Financial Management. Florida: The Dryden press. Central Bank of Rwanda. Retrieved from http://www.centralbank.go.ke/

CGAP (2009) Measuring results of micro finance Institutions. Retrieved from http://www.cgap.org

Christen, P., E. Rhyne, R. C. Vogel, \& C. McKean (1995). Maximizing the Outreach of Microenterprise Finance; An analysis of Successful Micro finance programs. Program and Operations Assessment Report, 10, USAID, Washington, D.C.

Deakins, D., \& Hussain, G. (1999). Risk assessment with asymmetric Information. International Journal of Bank Marketing, 12, 24-31.

Edward. B. (1993). Credit Management (6 ${ }^{\text {th }}$ ed.). Retrieved from http://www.gowerpublishing.com

Edwards, P., \& Turnbull (1994). Finance for small and medium sized enterprises.Information and the income gearing challenge. International Journal of marketing, 12(6), 3-9. https://doi.org/10.1108/02652329410048275

Eppy, I. (2005). Perceived Information Asymmetry, Bank lending Approaches and Bank Credit Accessibility by Smes in Uganda (Unpublished thesis) Makerere University

Fan, L., \& Shaffer, S. (2004). Efficiency versus Risk in Large Domestic US Banks. Managerial Finance, 30, 1-19. https://doi.org/10.1108/03074350410769245

Grover, P. (2002). Managing Credit: Is your Credit Policy Profitable? Retrieved from http://www.creditguru.com $(22 / 10 / 07)$

GTZ (2000). A Tool Kit for Micro Finance Institutions. Retrieved 08/06/2013 from http://www.microfinance gateway.org

Hulme, D., \& P. Mosley. (1996). Finance Against Poverty, Volume 1 and 2. Routledge: London.

Knox, S. (2004). Credit Analysis Technology in a Changing Business Environment. Boston: CFO Publishing Corp.

Ledgerwood. (1999) "Microfinance handbook: An institutional and financial perspective." Washington. The World Bank.

Mandal, M., Pandey, R., \& Prasad, A. (1998). Facial Expressions of Emotions and Schizophrenia. A Review Schizophrenia Bulletin, 24, 399-412. https://doi.org/10.1093/oxfordjournals.schbul.a033335

Meyer, R. L. (2002). Track Record of Financial Institutions in Assisting the Poor in Asia. ADB Institute Research Paper, No 49.

Michael A. Hitt, Robert E. Hoskisson, Richard A. Johnson \& Douglas D. Moesel. (1996). The Market for Corporate Control and Firm Innovation. The Academy of Management Journal, 39(5), 1084-1119

Micro capital (2007) Retrieved from http://www.microcapitalmonitor.com Micro Banking Standards project (2001) Retrieved from http: micro banking-mbb.org/

Mix Market. (2011). Country briefing Retrieved from http://www.mixmarket.org/mfi/country

Myers, C.S., \& Brealey, R.A. (2003). Principles of Corporate Finance. New York: McGraw-Hill.

Nelson, L. (2002). Solving Credit Problem. Retrieved 23/04/12 from http://www.cfo.com

Omino, G. (2005). Essays on Regulation and Supervision. Retrieved from http://www.microfinancegateway.org

Otero, M., \& E. Rhyne. (1994). The New World of Micro enterprise Finance. Hartford, Kumarian Press.

Pandey, I. M. (2008). Financial Management. Vikas Publishing House (PVT) Ltd, New Delhi Pang, J., Banking in 
Malaysia. Longman, 1991.

Pike, R., \& Neale, B. (1999). Corporate Finance and Investment: Decisions and Strategies. England: Prentice Hall.

Pyle, D. (1997). Bank Risk Management Theory. Conference on Risk Management and Deregulation in Banking. Jerusalem.

Scheufler, B. (2002a). Five Risks You Can Target with Best Practices. Retrieved 19/05/13 from http://www.dnb.com

The Seep Network and Alternative Credit Technologies (2005) Measuring Performance of Microfinance Institutions. A Framework for Reporting Analysis and Monitoring, Washing to D.C, USA.

Turyahebwa. A. (2013). Financial Performance in the Selected Microfinance Institutions In Uganda (unpublished master's thesis) Kampala International University, West campus. 